\title{
VIDEOGAMES AS MEANS OF INCREASING STUDENTS’ MOTIVATION
}

\section{Olexandr Horban}

ORCID 0000-0003-2321-5963

Doctor of Philosophical Sciences, Professor

Department of Philosophy, Borys Grinchenko Kyiv University

13-b Tymoshenka Str., 04212 Kyiv, Ukraine

o.horban@kubg.edu.ua

\section{Maria Maletska}

ORCID 0000-0003-3123-9500

Bachelor of Philosophy, Master Student

Department of Philosophy, Borys Grinchenko Kyiv University

13-b Tymoshenka Str., 04212 Kyiv, Ukraine

vernaya.lynx@gmail.com

https://doi.org/10.28925/2518-7635.2019.4.8

\section{ABSTRACT}

The article is devoted to the use of videogames in order to increase students' motivation and influence on educational process. Motivation is of particular interest to researchers because of its importance to learning and work with students. Several types of motivation apart from motivation for achieving: the motivation for power, the need for affiliation, the need to know (curiosity), the need for approval. Main components of the learning motivation are described. It is stated that videogames are complexphenomenon the main characteristics of which are apparatus for playing, interactivity and rules of playing game. Two ways of use of videogames in educational process are described: gamification and game-based learning. Typical elements of gamification which increase students' motivation are defined. It is concluded that videogames have significant impact on emotional state of students, encourage them to participate in learning, improve social interaction and decrease anxiety and fear of failure. The use of videogames in educational process can solve the problems with lack of motivation during the work in class.

Keywords: educational games, gamification, game-based learning, motivation, videogame.

(C) Oleksandr Horban, Maria Maletska, 2019

\section{INTRODUCTION}

Motivation is one of the most influential factors of success in learning. It has great impact on students' choices and behavior; such hard work as learning can only happen with enough motivation. It is linked strongly with emotions and perception 
of the educational process. Motivation can change during the whole way of learning and may vary from one subject to another. The motivation for learning is important not only in education but also in society in general.

The question "How to motivate students?" is still important in contemporary education. New teaching methods have to improve motivation in different ways. One of them is the use of videogames in learning. Videogames are not only a way of entertainment; they differ from other media by their complexity. Modern games may contain information about politics and economics, may simply advertise some products or tell deep stories about human life. They also may be created for education, communication or creativity. Such variability of videogames makes them an instrument for realization of different tasks: they can be used for fun or for certain purposes, especially for learning and simulation.

Game as a form of learning is widely used in education. Different forms of educational games increase students' interest and involvement in classroom work and homework. Although there are many educational videogames that can be helpful for teachers and instructors, they are still little used in universities, in particular in learning of human sciences. Videogames not only provide the means of practical aspects of learning, giving opportunities for studying on the base of simulations and models, they also are a way of increasing students' motivation and learning interest.

\section{BACKGROUND AND METHODOLOGY}

Videogame phenomenon in general is actively examined in contemporary world scientific discourse. Many researchers working in "game study" sphere pay attention to the use of videogames in educational purposes. Frasca (2001), game designer and academic researcher, focuses on serious games and mentions the possibility of use of videogames for learning. Bogost (2008) also notes ways of relations between videogames and learning and impact of videogames on thinking, views and opinions. Nardone (2017) mentions the possibility to use videogames in classroom. There are several examples that show the interest to videogames as means of learning.

The authors of the article in their previous works have repeatedly addressed the problem of using videogames in the educational process (Horban \& Maletska, 2019, p. 304-307). The main emphasis in the research was on the methodological potential of videogames in education (Horban, 2019, p. 19-34).

Videogames can improve learning process and be helpful with its different parts. Motivation is of particular interest of modern researchers. Many scientific works are devoted to the problems of students' motivation and means of its strengthening. Videogames are one of the possible means of it. Thus, the purpose of the article is to trace how the use of videogames increases students' motivation and influence on educational process. For the achieving of the purpose of the article, comparative method, system and typological methods were used. 


\section{RESULTS}

Motivation is a force that causes movement in human. Motivation is of particular interest to educational psychologists because of the crucial role it plays in student learning. However, the specific kind of motivation that is studied in the specialized setting of education differs qualitatively from the more general forms of motivation studied in other fields (Tohidi, \& Jabbari, 2012, p. 823). Motivation is deeply examined within the framework of many branches of science. Its importance for individual development and successful achievement of goals is evident.

Motivation in education can have several effects on how students learn and how they behave towards subject matter. It can: direct behavior toward particular goals, lead to increased effort and energy, increase initiation of, and persistence in, activities, enhance cognitive processing, determine what consequences are reinforcing, lead to improved performance (Tohidi, \& Jabbari, 2012, p. 823).

I.-O. Pânişoară and G. Pânişoară (2010) conclude that different definitions underline further characteristics of motivation:

1. Dynamics: motivation (1) initiates/energises/stimulates; (2) directs/ channels; and (3) supports/maintains a behaviour, everything being a dynamic, fluent process;

2. Motivation "is being made" by means of forces that lie within us;

3. The behavior generated by motivation is directed toward needs satisfaction (which generically were named "goal").

Student motivation naturally has to do with students' desire to participate in the learning process. However, it also concerns the reasons or goals that underlie their involvement or noninvolvement in academic activities. Although students may be equally motivated to perform a task, the sources of their motivation may differ (Lumsden, 1994). That is, they vary not only in level of motivation (i.e., how much motivation), but also in the orientation of that motivation (i.e., what type of motivation). Orientation of motivation concerns the underlying attitudes and goals that give rise to action - that is, it concerns the why of actions (Ryan, \& Deci, 2000: 54). Student may study at the university because of curiosity, understanding of importance of higher education or simply because he or she wants to procure the approval of a parent. The amount of motivation in this example is not necessary, but the nature and focus of it certainly is. Different motivation leads to the specific ways of achieving goals and to different results in general even if the amount of motivation is equal.

Different types of motivation can be described. Traditional education places emphasis on the motivation for achieving. Those persons motivated by this type of need are trying to achieve the excellence standards. However, through other types of motivation better results of educational process can be achieved. I.-O. Pânişoară and G. Pânişoară distinguish several types of motivation that can also have a certain impact on the teaching activity:

1. The motivation for power as the need to win acknowledgement, influence or control over other persons or groups in educational space; 
2. The need for affiliation that represents the need for maintaining social relationships with other persons;

3. The need to know (curiosity) that finds its fulfilment by means of the exploring activity;

4. The need for approval as a positive perceiving by others (Pânişoară, \& Pânişoară, 2010).

T. Seifert delineates several theories describing students' motivation. He mentions four theories that are prominent in contemporary educational psychology: selfefficacy theory, attribution theory, self-worth theory and achievement goal theory. These theories are based on different approaches to understanding motivation. However, they show connection between different patterns of behavior and emotions caused by the educational process (Seifert, 2004). The emotions can strengthen motivation, change its amount or focus. Emotional state of a student also influences greatly on his or her physical state, making the educational process comfortable and simply or, on the contrary, uncomfortable and difficult.

C. Frith highlights the following components of the motivation in learning:

1. Curiosity: People are naturally curious. Curiosity can be used as a motive for learning and nurtured in process of teaching. However, excessive pressure from a teacher may create anxiety rather than curiosity. So, one of the main tasks of the teacher is to keep students' curios and not to frighten them.

2. Self-efficacy is connected with positive emotions caused by the educational process. There are several ways to help students with forming self-efficacy. The final possible source of self-efficacy is physiological states. Self-efficacy may be strengthened in educational process.

3. Attitude towards educational process and learning may not be evident because some students may perform good or bad attitude only in the presence of teacher or instructor. Nevertheless, attitude is one of the most important components of motivation.

4. Need: The needs of individual students can vary greatly. The importance of this to motivation is the lower-level needs must be satisfied at one level before the nexgher order of needs become predominant in influencing behavior. Education fits into the realm of achieving higher level needs. Unsatisfied needs may also influence on the attitude towards educational process, teachers and tutors, institutions etc.

5. Competence is an intrinsic motive for learning that is highly related to selfefficacy. Some students need to prove their knowledge and skills, to undertake challenging tasks on their own. External support, respect and encouragement are important for the student to achieve competence.

6. External motivators are also important, especially when we talk about learning activity. There are many of them. One of them is learning environment that influences strongly on other components of students' motivation (Frith, 2009, p. 2-4).

While researchers use different frameworks for thinking about motivation, they essentially agree on the major factors students need to have in order to be motivated: competence (the belief that they're capable of doing something); autonomy/ 
control (the ability to set appropriate goals and see a correlation between effort and outcome); interest/value (a vested interest in the task and a feeling that its value is worth the effort to complete it), and relatedness (the need to feel part of a group or social context and exhibit behavior appropriate to that group) (Duta, 2015, p. 59).

Various means can be used to increase students' motivation. They often focus on forming one particular component of motivation or several of them, but it is hard to influence comprehensively on it. Videogames are complex phenomenon that may consist of video and audio, narrative and actions, plot and simulation. There is still no generally used definition of videogame. However, there are several common approaches of defining videogame. In world discourse main characteristics of "videogame" concept are:

1. Apparatus that coordinate game process, input and output;

2. Interaction with player - videogame must be interactive;

3. Some rules of interaction between player and world of the videogame (Horban, Maletska, 2018: p. 30). A degree of interaction may vary, the same as apparatus needed for playing and complexity of rules. Sometimes it is hard to tell how different videogames may belong to one category. However, such difference makes it possible to use videogames in many spheres of life.

The approach based on games makes the attainment of educational objectives and the learning process easier. Learning becomes more student-centred, interesting andmoreeffective. In emotionalarea, thegameinvolves awiderange of player'semotions. Games are successful as learning environment since they support multisensory, active, experiential and problem-based learning. Players must use previously learned information to improve their score in the game, and provide immediate feedback that allows players to test different hypotheses and learn from their actions. Games provide positive emotional experiences, changes attitude towards failures and mistakes. While in traditional learning failure often results in dissatisfaction of teachers and parents, fear of mistakes and feeling of anxiety, in the process of playing when the failure occurs the player can correct his mistakes over and over again. The only way to learn how to play is to repeat the game several times. Therefore, games show that mistakes are steps towards winning. Games also provide self-assessment tools such as the mechanisms score and the achievement of different levels, and use the social dimension to involve the community in the learning process. They allow sharing of the achievements, which otherwise remain invisible. Players also can reward each other, which not only motivates more, but also provides communication, which could not be possible in other learning activities. In the social area, the players can experience new identities and roles; they gave to make decisions according to the situation or environment in game and their role. Furthermore, besides the acquisition of knowledge, the game promotes logical-mathematical and critical thinking and the development of personal and social skills, language abilities, communication and collaboration skills, creative, and problem-solving capabilities (Pesare, Roselli, Corriero, \& Rossano, 2016).

There are several ways of use of videogames in education. Scientists distinguish gamification and game-based learning. There also are educational videogames as specific category of videogames. 
Gamificaiton is the practice of using game design elements, game mechanics and game thinking in non-game activities to motivate participants (Al-Azawi, AlFaliti, \& Al-Blushi, 2016, p. 133). There are manyexamples how gamification motivates behavior in education. This term relates to the use of game elements in general, not only videogames. Educational strategy with game elements is well known and widely used in contemporary education. Puzzles, geography games, board games used for learning purposes belong to gamification as well. Such activity is aimed at keeping students curious and it often allows involving students more actively and giving feedback in the process of interaction. Videogames made for gamification have specific structure. They form a framework for learning and systems for transforming education into gaming activity. It affects greatly on motivation because it adds more possibilities to compete and share achievements, encourages students to be curious and creative, changes attitude towards the educational process. Different types of motivation can be formed though videogames system because of the possibility to create different roles and types of activity for students with different needs.

Different authors enumerate typical elements of games that can be used in a "gamification" process and relate them with the diverse psychological theories that influence motivation enhancement. Some of the most significant examples are the following:

1. The points that the players obtain as the videogame develops. It triggers motivating mechanisms as positive reinforcement that is achieved by immediate recognition and obtaining rewards.

2. The selection of avatars and the possibility of character configuration are typical features that influence motivation positively according to psychological theories of interest and self-determination. Actions like these generate motivating mechanisms as the feeling of autonomy and personal implication in achieving the objective.

3. Tables with the highest scores rouse several motivating mechanisms and self-determination perspectives as competitiveness, feeling of power, feelings of individual capacity or group progress, improvement in social relations and in collaboration skills when the scores are shared in groups, etc.

4. Other features are: rewards that can be collected during the game and that imply a visual representation of the achievements; evolution graphs that compare different accomplishments made by the users so that they are aware of their own progress; small challenges that the user can fulfill during the game; and to provide the video game with a meaningful story. Many of these characteristics, as can be observed, are related with the motivating value of offering feedback to the user (Osma-Ruiz, Sáenz-Lechon, Gutiérrez-Arriola, Fraile, \& Marcano-Ganzo, 2015).

The example of gamification is ClassCraft system. ClassCraft is educational roleplaying game that is played by a teacher and students during the learning process. It is a background for learning of any subject to motivate students to participate fully in work in class and at home. Achievements and rewards in game reflect real progress of the student. Detailed analytics is also integrated into the system that gives possibility to get information about progress instantly. This system also 
teaches students to cooperate, mutual support gives additional points influencing on general marks of students who help others.

ClassCraft system is flexible enough for individualization of education, which sometimes is impossible in process of traditional learning. Such games give serious materials in form that provides active involvement and increases interest to

Game-based learning (GBL) broadly refers to the use of video games to support teaching and learning (Perrotta, Featherstone, Aston, \& Houghton, 2013). It is a form of education that is used to encourage students to participate in playing process and to make education more interest with the help of adding of entertainment to the educational process. Videogames are used as the part of educational process as model, example or reward.

One of the games that can be used for implementation of GBL is MineCraft. It gives possibility to build models and structures that can be used as examples; there is also a possibility of adding modifications that expand opportunities. Modification ClassCraft adds computers inside the computer: this modification makes simple programming possible inside of the game. MineCraft and other games with the possibility of modification can motivate and encourage students to improve the computer literacy. MineCraft also has its educational version developed particularly to be used in classroom.

\section{CONCLUSIONS}

Many of videogames does not require specific skills to use in educational process; they are user-friendly and simple to use. The use of them improves students' motivation comprehensively and gives opportunity to work with different types of motivation apart from traditional one. The motivation for power may be implemented through roleplaying and competitive games where students get the chance to win or to participate as influential character of the game. The need for affiliation is fulfilled by multiplayer videogames that make communication between students more active that during the traditional lessons. The need to know, curiosity, finds its fulfilment by means of the exploring the game, not only by means of exploring and learning the information given by teacher. The process of understanding how videogame works also increases interest to learning activities. The need for approval is fulfilled through rewards and achievements seen not only by teachers, but also by other students. Videogames also provide positive emotional reaction and change the attitude towards mistakes, make failure the step to further achievements. The use of videogames in educational process can increase students' participation in learning and solve the problems with lack of motivation during the work in class.

\section{REFERENCES}

Al-Azawi, R., Al-Faliti, F., \& Al-Blushi, M. (2016). Educational Gamification

Vs. Game Based Learning: Comparative Study. International Journal 
of Innovation, Management and Technology, 131-136. https://doi.org/10.18178/ ijimt.2016.7.4.659

Bogost, I. (2008). The Rhetoric of Video Games. The Ecology of Games: Connecting Youth, Games, and Learning. Edited by Katie Salen. The John D. and Catherine T. MacArthur Foundation Series on Digital Media and Learning. Cambridge, MA: The MIT Press, 2008. P. 117-140. doi:10.1162/dmal.9780262693646.117

Duta, N. (2015). Importance of the motivation of students for learning - Premise for academic performances. Inventory of reasons for which students learn. Euromentor, 6, 54-72.

Frasca, G. (2001). Videogames of the oppressed: Videogames as a means for critical thinking and debate. MA. Thesis, Atlanta: Georgia Institute of Technology.

Frith, C. (2009) Motivation to learn. Educational Communications and Technology, University of Saskatchewan.

Horban, O., Maletska, M. (2018). Basic approaches to the definition of the concept of "videogame" as an element of modern scientific discourse. Skhid, 3(155), 2933. http://dx.doi.org/10.21847/1728-9343.2018.3(155).139675

Horban O., Maletska M. (2019). Educational Aspects of Videogames (in Ukrainian). Kyiv Philosophical Studies-2019. Materials of the scientific conference. May 16-17, 2019, Kyiv, Ukraine, 304-307.

Horban O. (2019). Educational Potential of Videogames: Methodological Background. Educational discourse, 3-4 (26-27), 19-34. https://doi. org/10.28925/2312-5829.2019.3-4.1934 (in Ukrainian).

Lumsden, L.S. \& ERIC Clearinghouse on Educational Management (1994). Student Motivation to Learn. Eugene, OR : ERIC Clearinghouse on Educational Management, https://eric.ed.gov/?id=ED370200

Nardone, R., (2017). Videogames between ethics and politics, Ricerche di Pedagogia e Didattica, Journal of Theories and Research in Education, No. 12(2), 41-55, https://doi.org/10.6092/issn.1970-2221/7072

Osma-Ruiz, V. J., Sáenz-Lechon, N., Gutiérrez-Arriola, J. M., Fraile, R., \& MarcanoGanzo, R. (2015). Learning English is Fun! Increasing Motivation Through Video Games. Proceedings of ICERI2015 Conference. 16th-18th November 2015, Seville, Spain. 10.

Pânişoară, I.-O., \& Pânişoară, G. (2010). Motivarea pentru cariera didactică = Motivation for teaching career. Bucureşti: Editura Universităţii din Bucureşti.

Perrotta C., Featherstone G., Aston H., \& Houghton E. (2013). Game-based Learning: Latest Evidence and Future Directions, Slough, NFER.

Pesare, E., Roselli, T., Corriero, N., \& Rossano, V. (2016). Game-based learning and Gamification to promote engagement and motivation in medical learning contexts. Smart Learning Environments, 3(1), 5. https://doi.org/10.1186/s40561016-0028-0

Ryan, R.M., \& Deci, E.L., (2000), Intrinsic and Extrinsic Motivations: Classic Definitions and New Directions, in Contemporary Educational Psychology, 25, 54-67.

Seifert, T. (2004). Understanding student motivation. Educational Research, 46(2), 137-149. https://doi.org/10.1080/0013188042000222421 
Tohidi, H., \& Jabbari, M. M. (2012). The effects of motivation in education. Procedia - Social and Behavioral Sciences, 31, 820-824. https://doi.org/10.1016/j. sbspro.2011.12.148

\section{ВІДЕОІГРИ ЯК ЗАСІБ ПІДВИЩЕННЯ МОТИВАЦІЇ СТУДЕНТІВ}

Горбань Олександр, доктор філософських наук, професор кафедри філософіі, Київський університет імені Бориса Грінченка, вул. Тимошенка, 13-6, 04212 Київ, Україна, o.horban@kubg.edu.ua

Малецька Марія, бакалавр філософії, магістрант кафедри філософії, Київський університет імені Бориса Грінченка, вул. Тимошенка, 13-б, 04212 Київ, Україна, vernaya.lynx@gmail.com

В статті розглянуті можливості використання відеоігор в навчальному процесі з метою підвищення мотивації студентів. Феномен мотивації до навчальної діяльності має значний дослідницький потенціал в зв'язку з їі великими можливостями стимулювати студентів до навчання. Окрім безпосереднво мотивації зі спрямуванням на досягнення, авторами статті виділено наступні типи мотивації: мотивація як прагнення влади, потреба у приналежності, потреба у пізнанні (цікавість) та потреба у схваленні. Проаналізовано основні компоненти навчальної мотивачії. Зазначено, щз відеогра ие складний феномен, основними рисами якого є потреба у апаратурі для гри, інтеракція з гравием та правила, на яких побудовано гру. Описано два основних способи використання відеоігор у навчальному процесі: геймібікачія та "gатеbased learning". Зроблено висновок про те, що відеоігри мають значний вплив на емоційний стан студентів, заохочують їх брати участь у навчальному процесі, підвищують рівень соціальної взаємодії, знижують тривожність та страх поразки. Використання відеоігор в освіті дає змогувиріиити проблеми знедостатнім рівнем мотивациї протягом аудиторноїроботи.

Ключові слова: відеогра, геймібікачія, мотивачія, навчання на основі ігор, освітні ігри. 